\title{
Tuberculosis Coaching Program towards the Performance of Drug Consumption Supervisors and Drug Taking Compliance among Tuberculosis Patients
}

\author{
Munjiati", Herry Prasetyo, Ulfah Agus Sukrillah, Petrus Nugroho, Ani Kuswati, Mukhadiono \\ Poltekkes Kemenkes Semaran, Indonesia
}

*Corresponding Author: Munjiati, Poltekkes Kemenkes Semarang, Indonesia

\begin{abstract}
Background: The role of supervisors to ensure medicine taking is crucial in assisting the tuberculosis patients during treatment as their tasks are to monitor and remind the patients to take medication regularly in order to achieve the optimal treatment.

The Objective: The study is to determine the effect of tuberculosis coaching program towards performance of Drug Consumption Supervisors or in Indonesia is known as Pengawas Minum Obat in monitoring the patients to take medication and compliance with anti-tuberculosis drug prescription.
\end{abstract}

Method: The method used is a quasi-experimental with pre-post test control design. The subjects were health workers, community leaders and family members of patients who met the inclusion criteria to be used as supervisors. The study conducted in the Community Health Center Sokaraja II Banyumas District, Central Java, and Indonesia. A random sampling method is used and the data collection obtained through a questionnaire. Data analysis applied Wilcoxon and Mann-Whitney to determine difference performance levels before and after treatment.

Result: The result of research shows the increasing knowledge, communication skills and the performance of supervisors in implementing the tuberculosis program. Based on the Wilcoxon test, there is a significant difference to knowledge, communication skills and their performance before and after coaching.

Conclusion: Coaching tuberculosis programs can improve the performance of supervisors characterized by increased knowledge and communication skills in overseeing the ability of the patient to adhere to taking anti-tuberculosis drugs. Monitoring and evaluation need to be done to maintain the performance of supervisors.

Keywords: Coaching, Tuberculosis program, Performance, Drug Consumption Supervisors

\section{INTRODUCTION}

Tuberculosis coaching program is an important and urgent to be done by the community health workers especially those working in the health center. Coaching is a process whereby a person given the opportunity to gain knowledge and improve skills, which are useful in the development of career (Stone, 2005). Coaching aims to improve and enhance the performance of supervisors taking medicine that comes not from health professionals in supporting the program of drinking anti tuberculosis drugs to completion, Drug Consumption Supervisor ability to communicate can be improved through coaching to ensure that TB patients take medication obedient and submissive.
Nurse or health worker will be assigned as Drug Consumption Supervisor or Pengawas Minum Obat (PMO) for tuberculosis if the patient has committed to come for treatment and conduct other investigations regularly scheduled at the health care center. PMO are healthcare workers such as midwives, community nurses, sanitarians, interpreter of immunization (Kementrian Kesehatan, 2014).

However, the ability or competence of PMO coming from family members and others (cadre or public figure) is very different with the ones derived from health officials. One of them is the ability of different communication skills: persuasion to influence and convince the patient to undergo a tuberculosis treatment program. Rungapadiachi (1999) indicated that through 
persuasion, someone will try with all strength and continue to try to influence the beliefs and expectations of others during the process of interaction, so that tuberculosis patients can obey undergoing treatment until completed as well as taking the drug as scheduled despite the possible side effects, and perform sputum laboratory tests schedule.

Trainings for PMO become crucial matters need to be given to support the recovery in the treatment of patients with tuberculosis. Through coaching activities, there will be a process of exchanging any information that can give a particular meaning or significance for participants (Taylor, Francine \& Le Mone, 1997). The task of PMOs is very important, because they are as people closest to tuberculosis patients in support of treatment program. The task among others are in charge of patients taking the drug completely, reminding the patient's sputum examination over, advising patients to keep taking the medication even if side effects are undesirable and referring tuberculosis patients to the hospital when the side effects experienced by patients increase severely.

Compliance in the tuberculosis program is a form of tuberculosis person's behavior to execute commands from doctors and health workers in the treatment (Smet, 1994). Likewise Niven (2002) also states that compliance is an obedience program for tuberculosis in resolving drinking anti tuberculosis drugs until recovered. As an implication, the patient can be cured and healthy again, so that the risk of transmission to people around him does not happen.

Compliance with the treatment for tuberculosis needs to be supported by the next of kin as a support system. Hutapea (2010) states that the family of the patient is a major supporter of tuberculosis patients to complete the program. The role of the family is very important, whereby when a family member is sick, other family members will seek medical assistance. Strong family support will assist people with tuberculosis to undergo treatment completely.

\section{MATERIALS AND MethodS}

The design used in this study is quasiexperimental with pre-post test with control design. Furthermore, this study measures the difference between before and after treatment in the intervention group and the control group. The treatment given training (coaching) tuberculosis program through communication skills of persuasion.

The population in this study is the Consumption Drug Supervisor or Pengawas Minum Obat (PMO) not from health officials in the Health Community Center Sokaraja Banyumas regency. The sample was randomly selected with the inclusion criteria coming from volunteers, community leaders, and family members at home: husband, wife, close family members with patients.

There are three principal types of activities in the implementation of this research

* Pre-test was conducted in the intervention group and the control group. In the intervention group: the PMO attended the tuberculosis coaching program through communication skills of persuasion.

* The tuberculosis coaching program implementation stage was given in the form of theoretical classes of persuasion communication skills. This theory classes was conducted during 4 meetings discussing material on basic information about tuberculosis. At the end of the theory of class activities, participants were given the opportunity to discuss, question and answer and reflection on the results of the theory class in communication skills.

* Post-test was conducted after participants completed the coaching tuberculosis programs both classroom theory and practice. Post-test was done 3 times after coaching treatment for 3 consecutive months with assistance from the health tuberculosis volunteers.

\section{RESUlt AND DisCUSSION}

The majority of respondents in the age range 3150 years, either the intervention group or the control group. The number of respondents aged 31-50 years in the intervention group were 13 people $(59.1 \%)$ and the control group was as many as 14 people $(66.6 \%)$.

Furthermore, based on the education level categories, it can be described the number of respondents in the intervention group of 11 people $(50 \%)$ had a high school education level. Whereas, in the control group, the respondents' education level junior and senior high graduates have the same number are respectively 8 respondents $(38.1 \%)$. 
Tuberculosis Coaching Program towards the Performance of Drug Consumption Supervisors and Drug Taking Compliance among Tuberculosis Patients

Characteristic of respondents by category of sex, most women are either the intervention group or the control group. The number of women in the intervention group were 19 people $(86.4 \%)$ and men were three people (13.6\%). Likewise, in the control group the number of women were 14 people $(63.6 \%)$ and were $7(31.8 \%)$.

Relationship with the tuberculosis patients in the intervention group was as a husband / wife, children, parents, brothers and cadres. Relationship with the patient as spouse and children was five people (22.7\%), parents were 4 people (18.2) and tuberculosis cadre was 7 people (31.8\%). Meanwhile, in the control group tuberculosis patient relationship was son, brother and cadres. A total of seven respondents $(33.3 \%)$ in the control group had a relationship as children. Meanwhile, respondents with a tuberculosis patient relationship as brothers were 11 people (52.4\%).

Prior to coaching treatment of tuberculosis program, the level of PMO's knowledge is still lacking as many as 17 people $(77 \%)$. After attending coaching tuberculosis program in 1-3 months, the participants still had a pretty good knowledge. After attending coaching tuberculosis coaching program,

PMO's ability increases in the range of quite well. However, in the second month of post coaching abilities decline as much as 5 people (23\%). Then, a team of researchers and health workers provide guidance in the third month and post test results obtained the communication skills ability again increase in the range of 4 people and good enough about 18 people.

Table1. Consumption Drug Supervisor performance in overseeing the adherence to medication

\begin{tabular}{|c|c|c|c|c|c|c|c|c|c|}
\hline \multirow[t]{3}{*}{ No. } & \multirow{3}{*}{$\begin{array}{c}\text { Consumption Drug } \\
\text { Supervisor } \\
\text { performance }\end{array}$} & \multicolumn{8}{|c|}{ Coaching Treatment } \\
\hline & & \multirow{2}{*}{\multicolumn{2}{|c|}{ Pre-Test }} & \multicolumn{6}{|c|}{ Post-Test th- Month } \\
\hline & & & & 1 & $\%$ & 2 & & 3 & \\
\hline 1. & Poor & 10 & 45 & - & - & - & - & - & - \\
\hline 2 & Satisfactory & 12 & 55 & 8 & 36 & 20 & 91 & - & - \\
\hline \multirow[t]{2}{*}{3} & Good & - & - & 14 & 64 & 2 & 9 & 22 & 100 \\
\hline & & 22 & 100 & 22 & 100 & 22 & 100 & 22 & 100 \\
\hline
\end{tabular}

Table 1 explained that the performance of Drug Consumption Supervisor in overseeing the patients before training were in the poor and satisfactory category. In post coaching, the performance increased, where as many as 14 people $(64 \%)$ in good categories and $8(36 \%)$ in the satisfactory category. In the end, after caring for three months by a team of researchers and health workers the performance of 22 Drug Consumption Supervisors (100\%) reach good level.

Table2.The Significance of Drug Consumption Supervisor's Knowledge

\begin{tabular}{|l|l|l|l|l|}
\hline \multirow{2}{*}{$\begin{array}{l}\text { Variabel } \\
\text { Knowled } \\
\text { ge }\end{array}$} & \multicolumn{4}{|c|}{ Groups } \\
\cline { 2 - 5 } & $\mathrm{Z}$ & $\begin{array}{l}\text { Asymp. } \\
\text { Sig. }\end{array}$ & $\mathrm{Z}$ & $\begin{array}{l}\text { Asymp } \\
\text {. Sig. }\end{array}$ \\
\hline Month 1 & -4.165 & 0.000 & -0.375 & 0.169 \\
\hline Month 2 & -4.021 & 0.000 & -0.347 & 0.729 \\
\hline Month 3 & -4.149 & 0.000 & -2.333 & 0.020 \\
\hline
\end{tabular}

Based on Wilcoxon Signed Test in Table 2, it can be concluded that there is a significant difference to the knowledge of Drug Consumption Supervisor in tuberculosis program coaching before and after treatment. It is based on the provisions of Asymp. Sig. which is smaller than or equal to 0.05 indicating that $\mathrm{Ha}$ is accepted and Ho is rejected.

Table3.The communication skills of Drug Consumption Supervisor

\begin{tabular}{|l|l|l|l|l|}
\hline \multirow{2}{*}{$\begin{array}{c}\text { Communic } \\
\text { ation Skills }\end{array}$} & \multicolumn{4}{|c|}{ Groups } \\
\cline { 2 - 5 } & $\mathrm{Z}$ & $\begin{array}{l}\text { Asymp } \\
\text {. Sig }\end{array}$ & $\mathrm{Z}$ & $\begin{array}{l}\text { Asym } \\
\text { p. Sig }\end{array}$ \\
\hline Month 1 & -4.226 & 0.000 & -2.683 & 0.007 \\
\hline Month 2 & -4.291 & 0.000 & -0.258 & 0.796 \\
\hline Month 3 & -4.164 & 0.000 & -2.296 & 0.022 \\
\hline
\end{tabular}

Based on Wilcox on Signed Test in Table 3, it can be concluded that there is a significant difference to the communication skills of Drug Consumption Supervisor in tuberculosis program coaching before and after treatment. It is based on the provisions of Asymp. Sig.which is smaller than or equal to 0.05 indicating that $\mathrm{Ha}$ is accepted and Ho is rejected.

Based on Wilcoxon Signed Test in Table 4, it can be concluded that there is a significant difference to the performance of Drug Consumption Supervisor in tuberculosis program coaching before and after treatment. It is based on the provisions of Asymp. Sig. which 
is smaller than or equal to 0.05 indicating that $\mathrm{Ha}$ is accepted and Ho is rejected.

Table4. Performance values of Drug Consumption Supervisor

\begin{tabular}{|l|l|l|l|l|}
\hline \multirow{2}{*}{$\begin{array}{c}\text { Performan } \\
\text { ce }\end{array}$} & \multicolumn{4}{|c|}{ Groups } \\
\cline { 2 - 5 } & $\mathrm{Z}$ & $\begin{array}{l}\text { Asymp. } \\
\text { Sig }\end{array}$ & $\mathrm{Z}$ & $\begin{array}{l}\text { Asymp. } \\
\text { Sig }\end{array}$ \\
\hline Month 1 & -4.134 & 0.000 & -2.389 & 0.017 \\
\hline Month 2 & -4.027 & 0.000 & -0.200 & 0.842 \\
\hline Month 3 & -4.140 & 0.000 & -2.437 & 0.015 \\
\hline
\end{tabular}

Support from those closest to tuberculosis will help them taking medication regularly even though the existence of less pleasant side effect. Research conducted by Syam, Riskiyani \& Rachman (2013) concluded that the emotional support received by the tuberculosis patient in the form of attention and empathy can improve their compliance in taking medication. Support shall include the fulfillment of daily needs such as eating and drinking, washing, bathing and providing drugs to be taken by patients.

The results of this study show that Drug Consumption Supervisor's knowledge about tuberculosis before and after participating in coaching indicates significant differences. Similarly, research conducted by Saftarina, Islamy \& Rasely (2012) states that there is a relationship between the levels of Drug Consumption Supervisor's education against medicine taking regularity in patients with tuberculosis.

The results of this study that tuberculosis coaching programs will facilitate the officer is in accordance with the theory of coaching delivered by Whitmore (2008) stated that coaching will help maximize the potential of the participants so that they can maximize their performance.

The results of previous studies relating to the treatment of tuberculosis focused tuberculosis patient compliance in taking OAT has been done, but the coaching treatment of tuberculosis program has not explored. Research conducted by Hutapea (2005) states as much as $69.4 \%$ of tuberculosis patients take medication regularly, and $30.6 \%$ are not obedient to take medication because of forgetting. Likewise in research Hutapea (2005) also states there was a 50.7\% acquisition of the data of family members of patients who did not give attention and support to the development of treatment performed by the patient. Thus, the performance Drug Consumption Supervisor coming from a family member close to the patient needs to be enhanced through training.

Furthermore, research conducted by the Paradise (2012) concluded only 19 DRUG consumption of a total of 32 Drug Consumption Supervisors $(59 \%)$ of an active role in supporting the successful treatment of pulmonary tuberculosis. Thus, there are 13 Drug Consumption Supervisors (41\%) need to improve their participation in the treatment of patients with tuberculosis. Thus, patients with pulmonary tuberculosis can complete the antituberculosis treatment and a healthy return.

Similarly, research conducted by Irma (2009) declared tuberculosis patients aged 50 years and older often neglect suffered tuberculosis. As a result, the longer the disease becomes the more severe and potentially rubs off on other family members. As an implication, the role of tuberculosis especially who live in supporting the healing of tuberculosis need to be improved?

\section{CONCLuSion}

The treatment of tuberculosis needs serious effort by the patient to take medication regularly. The problem is that the patient needs supervising regularly to ensure that the medicine is taken properly in accordance with the dosage prescribed in the long term. With the limited number of official health workers, the family members can be trained as the Drug Consumption Supervisors or Pengawas Minum Obat. The research has proven that the proper training given to the family members increase the compliance to take the medicine regularly as the family members serving as Drug Consumption Supervisors are equipped with persuasive communication skills.

\section{REFERENCES}

[1] Darmawan, D. 2006. Teori Komunikasi. Bandung: Arum Mandiri Press.

[2] Firdaus, KMZ. 2012. Pengaruh peranan pengawas menelan obat (DRUG CONSUMPTION SUPERVISOR ) terhadap keberhasilan pengobatan TB paru di wilayah kerja Puskesmas Baki Sukoharjo. FIK UMS Surakarta

[3] Hutapea, TP. 2005. Pengaruh dukungan keluarga terhadap kepatuhan minum obat anti tuberkulosis. RSUD Malang.

[4] Hutapea, TP. 2010. Pengaruh dukungan keluarga terhadap kepatuhan minum obat anti 
Tuberculosis Coaching Program towards the Performance of Drug Consumption Supervisors and Drug Taking Compliance among Tuberculosis Patients

tuberkulosis. Media litbangkes Vol. 21 No. 2. Jakarta.

[5] Kemenkes RI. 2014. Pedoman Nasional Penanggulangan TB. Jakarta.

[6] Niven, N. 2002. Perilaku kesehatan dalam psikologi kesehatan. Edisi ke-2. Penerbit buku kedokteran EGC: Jakarta

[7] Rungapadiachi, DM. 1999. Interpersonal communication and psychology for health professionals teory and practice. Jorand Hill, Oxford: Butterworth-Heinemann.

[8] Saftarina, F, Islamy, N \& Rasely, M.C. 2012. Hubungan pendidikan dan pengetahuan pengawas minum obat terhadap keteraturan minum obat anti tuberkulosis pada penderita tuberkulosis paru di kabupaten Tulang Bawang
Barat. Prosiding SNSMAIP III-ISBN No.978602-98559-1-3.

[9] Smet, B. 1994. Psikologi Pendidikan. Jakarta. Gramedia Widiasarana Indonesia.

[10] Stone, R.J. 2005. Human Resources Management, Fifth Edition. Australia. Willey

[11] Syam, M.S, Riskiyani, S. \& Rachman, W.A. 2013. Dukungan sosial penderita tuberkulosis paru di wilayah kerja Puskesmas Ajangale Kabupaten Bone. FKM, Univ. Hasanuddin Makasar.

[12] Taylor C, Lilis C, Le Mone. P. 1997. Fundamental of Nursing. The art and science of nursing care. Philadelphia: Lippincott-Raven Publishers

Citation: Munjiati, Herry Prasetyo, Ulfah Agus Sukrillah, Petrus Nugroho, Ani Kuswati \& Mukhadiono. Tuberculosis Coaching Program towards the Performance of Drug Consumption Supervisors and Drug Taking Compliance among Tuberculosis Patients. ARC Journal of Public Health and Community Medicine.2018; 3(1):1-5. DOI: dx.doi.org/ 10.20431/2456-0596.0301001.

Copyright: (C) 2018 Authors. This is an open-access article distributed under the terms of the Creative Commons Attribution License, which permits unrestricted use, distribution, and reproduction in any medium, provided the original author and source are credited. 